\title{
Peculiarities of intercultural competence in teaching foreign languages
}

\author{
Peculiaridades de la competencia intercultural en la enseñanza de lenguas extranjeras
}

\begin{abstract}
The article deals with the issues related to intercultural competence in teaching foreign languages. The modern world and society are increasingly in need of people who can think creatively, analyze, and understand others. And a foreign language is one of the best tools to develop these skills. Comparison of countries, people, customs, traditions, cultural heritage stimulates and motivates the desire to increase and deepen the knowledge about other countries and their own country. At the center of the modern personalityoriented concept is the personality of the student, his needs, and interests. The main goal of teaching a foreign language is seen in the formation of communicative and intercultural competencies among pupils. In the process of teaching foreign languages, both competencies are formed interconnected intercultural competence is formed based on communicative and in the process of its development. Each lesson of a foreign language is a crossroads of cultures this is the practice of intercultural communication because each word reflects a foreign world and a foreign culture.
\end{abstract}

Key words: intercultural communication, communication, culture, knowledge, intercultural competence, country

\section{RESUMEN}

El artículo trata de las cuestiones relacionadas con la competencia intercultural en la enseńanza de idiomas extranjeros. El mundo y la sociedad modernos necesitan cada vez más personas que puedan pensar creativamente, analizar y comprender a los demás. Y una lengua extranjera es una de las mejores herramientas para desarrollar estas habilidades. La comparación de países, pueblos, costumbres, tradiciones, patrimonio cultural estimula y motiva el deseo de aumentar y profundizar el conocimiento sobre otros países y el propio. En el centro del concepto moderno orientado a la personalidad está la personalidad del estudiante, sus necesidades e intereses. El objetivo principal de la enseñanza de una lengua extranjera se ve en la formación de competencias comunicativas e interculturales entre los alumnos. En el proceso de enseñanza de las lenguas extranjeras, ambas competencias se forman interconectadas la competencia intercultural se forma sobre la base comunicativa y en el proceso de su desarrollo. Cada lección de un idioma extranjero es una encrucijada de culturas, es la práctica de la comunicación intercultural porque cada palabra refleja un mundo y una cultura extranjera.

Palabras clave: comunicación intercultural, comunicación, cultura, conocimiento, competencia intercultural, país. 
The problem of intercultural communication in the study of foreign languages is that between the teaching of foreign languages and intercultural communication there is a single, complementary relationship. Every lesson of a foreign language, wherever it takes place, at school or within the walls of a university is a practical encounter with a different culture, primarily through its main carrier - language.

The maximum development of communicative abilities is the main, promising, but very difficult task facing foreign language teachers. To solve it, it is necessary to master new teaching methods aimed at developing all four types of language proficiency, and fundamentally new materials with which you can teach people to communicate effectively. In this case, of course, it would be wrong to rush from one extreme to the other and abandon all the old methods: you must carefully select all the best, useful, and tested by teaching practice.

Each foreign word reflects a foreign culture, behind each word there is a subjective, due only to this linguistic culture, a peculiar impression of the world. Foreign languages in Uzbekistan, and their teaching are very much in demand today, as there is an urgent need to use such knowledge in everyday life. This, of course, has an impact on teaching methods. The increasing demand for teaching foreign languages, in turn, dictates its own conditions.

Now, nobody is interested in grammar rules, and even more so, the history itself and the theory of language. Modern living conditions require learning a foreign language, primarily functionality. Now they want to not know the language, but use it as a means of real communication with native speakers of other cultures. In this regard, it was necessary to radically change the view on the teaching of a foreign language, taking into account more attention and a bias on linguistics and intercultural communication.

The solution to this pragmatic problem is possible only under one condition - that a rather solid fundamental theoretical base will be created. To create it, it is necessary, first of all: 1) to apply the results of theoretical works in philology to the practice of teaching foreign languages; 2) theoretically comprehend and summarize the vast practical experience of teachers of foreign languages. With the traditional approach to learning foreign languages, the main teaching methodology was reading texts in a foreign language. And this concerned not only the school level of education, but also higher, university. The topic of everyday communication was represented by the same texts, only relating to everyday subjects, however, few of such specialists, having read such texts, could adequately behave in a real situation that would require the application of knowledge of a practical foreign language, rather than its large-scale literary side.

Now, teachers are striving to teach how to practically use the available linguistic material. Now, on the basis of higher education, teaching a foreign language is perceived precisely as a means of everyday communication with native speakers of a different culture. The task of higher education is to form a well-educated person who has in his arsenal fundamental training not only in narrow specializations, but also in a broad sense, for example, as learning a foreign language without reference to the chosen profession, that is, technical specialists should be proficient not only and not so much technical English, or another foreign language, but also be able to apply it, first of all, with similar specialists who only speak another foreign language.

The very concept of intercultural communication is based on an equal cultural interaction between representatives of various linguistic and cultural communities, taking into account their originality and originality, which leads to the need to identify the universal based on a comparison of foreign and own cultures. Modern teaching of a foreign language is impossible without instilling in students a foreign language culture. Most methodologists focus on the current state of the theory and practice of teaching a foreign language with a pronounced communicative orientation, which contributes to the comprehensive development of personality, the development of spiritual values of students. Intercultural communication training cannot exist without the inclusion of a linguistic and regional aspect in the learning process.

The purpose of education is not just knowledge, skills, but the formation of "key competencies" (Gudkov D. B. 2003), which must be mastered for the socialization of a person, for his "productive adaptation" to this world.

In the modern dictionary of foreign words we read: "Competence translated from Latin competentia means a range of issues in which a person is knowledgeable, has knowledge and experience" (Bulyko A.N. (2005). The Linguodidactic Encyclopedic Dictionary interprets this concept as "a combination of knowledge, skills, abilities, formed in the process of learning a particular discipline, as well as the ability to perform any activity on the basis of acquired knowledge, skills, abilities". ( Gudkov D. B. 2003) Khutorskoy A.V. writes that "competence is an alienated, predetermined social demand (norm) for the student's educational preparation, which is necessary for his high-quality productive activity in a certain field (Khutorsky A.V. 2003). An analysis of the work on the problem of competence is presented by Zimnaya The author notes that the founder of competencies G. Khalazh believes that competencies are "An answer to the challenges facing Europe (maintaining a democratic open society, multilingualism, multiculture, new labor market requirements, the development of integrated organizations...)". A.I. Surygin divides the two concepts of competence and competence and concludes that competence is a "phenomenon, a range of issues," and competence is "Property, quality of personality." (Surygin A.I. 2001)

Based on these findings, the author proposes the following definition: "competence is the content of education, which, when acquired by students, forms its competence in any field of activity".

As you can see, there is no single interpretation of this concept, therefore we will assume that the acquired knowledge is necessary for a person to show his abilities in a particular situation.

The issue of types of competencies is also controversial. According to the list of five key competencies adopted by the Council of Europe, a personality standard should include the following: 1) political and social competencies related to the 
ability to take responsibility in decision-making and participate in non-violent conflict resolution; 2) competencies that allow living in a multicultural society, promoting understanding and willingness to live in a good neighborhood with other cultures, "education should" equip "young people with intercultural competencies, such as accepting differences, respect for others and the ability to live with people of other cultures, languages and religions "; 3) competencies involving oral and written communication, knowledge of several foreign languages; 4) competencies associated with the informatization of society, involving the possession of new technologies, an understanding of their application, and a critical attitude to the information disseminated; 5) the ability to lifelong learning both professionally and socially (Bobkova V.N. 2006).

Possession of intercultural competence is one of the basic competencies of a modern specialist. What is meant by intercultural competence? S.E. Tsvetkova, analyzing this concept, writes that in "domestic studies on the problem of intercultural competence, the latter is defined as the ability of members of a certain cultural community to seek understanding in the process of interacting with representatives of another culture using compensatory strategies to prevent conflicts of "one's "and another's and create during the course of the interaction, a new intercultural communicative community." G.V. Elizarova considers intercultural competence as an integral part of foreign language communicative competence, but with some "additional components based on taking into account the projection of culture on the sphere of communication". This means that it is impossible to achieve mutual understanding in the process of communication without taking into account ethical standards and rules adopted by native speakers. Intercultural competence, according to M.G. Evdokimova, "consists in the ability to take into account intercultural differences in the process of foreign language communication" and is formed by "the totality of intercultural aspects of the content of foreign language communicative competence".

The purpose of the formation of intercultural competence is indicated by G.V. Elizarova as "achieving such a quality of a linguistic personality that will allow her to go beyond her own culture and acquire the qualities of a mediator of cultures without losing her own cultural identity".

An analysis of pedagogical research on the problem of the formation of intercultural competence allows us to conclude that this problem is in the spotlight. The formation of intercultural competence of foreign students in the process of teaching foreign language will become possible and effective if texts of a national theme are one of the main components of the content of the training. The purpose of these texts is not only to get acquainted with a foreign sociocultural environment, its customs, traditions, rules of conduct, but, above all, to recognize and accept the values of another culture in comparison with the values of one's own culture, to form the ability to see differences, understand and accept them try to find common ground. A foreign student, falling into a foreign environment, encountering foreign speakers, representatives of a different culture, is himself a native speaker of a language and culture, his native, close and beloved. When we get into a foreign city, country, in other words, into a non-native sociocultural environment, we sharply perceive "our own", our native, and we show special interest in this, enthusiastically sharing this with "strangers".

In our case, texts of a national theme (not regional geographic), already placed in the study guide, will become part of the model for the formation of intercultural competence of foreign students. The developed system of exercises will help to master the lexical, grammatical, speech material of texts. The material will be fixed by going out into the environment of the language being studied for direct contact with native speakers. The developed test system (listening, reading, speaking, vocabulary and grammar) will become control.

Despite all the differences in methodological approaches and aspects of intercultural communication research in different sciences, most scholars are of the opinion that the main objectives of research in the field of intercultural communication are:

- definition of the subject, methodology and conceptual apparatus of the theory of intercultural communication;

- identification of the place of the theory of intercultural communication among other sciences;

- the formation and development among participants of intercultural competence and competence, cultural sensitivity, the ability to correctly interpret specific manifestations of communicative behavior and a tolerant attitude towards it;

- development of a methodology for teaching practical skills in communicating with representatives of other cultures.

So, during the development of intercultural communication as an independent discipline, three main areas of research have developed: descriptive, cultural, anthropological and systemic; Three approaches have been formed on the basis of communication: functionalistic, interpretative and critical. And also recently, in connection with globalization, the development of social sciences and the increasing penetration of information technology into the field of communication, new areas of research have been outlined. 


\section{REFERENCES}

Bakhronova, D., \& Abdullayeva, S. Y. (2019) Axiological Evaluation as the Base of Knowledge and Cultural Research of Spanish and Uzbek Languages. International Journal of Recent Technology and Engineering, 8(2S11), 3755-3759. https:// doi.org/10.35940/ijrte.b1486.0982s1119

Bobkova V. N. (2006) Regional geography as a form of inculcating interest in the study of foreign languages. IYASH. No. 5.

Bulyko A. N. (2005) Modern dictionary offoreign words. Over 25 thousand words and phrases. Ed. 2nd, rev. And additional. "Martin".

Gudkov D. B. (2003) Theory and practice of intercultural communication. ITDGK “Gnosis". https://doi.org/10.3897/ ap.1.e0375

Khutorsky A.V. (2003) Didactic heuristics. Theory and technology of creative learning. Publishing House of Moscow State University.

Leontovich O.A. (2003) Russia and the USA: An Introduction to Intercultural Communication. Change.

Surygin A. I. (2001) Pedagogical design of the system of pre-university training of foreign students. Zlatoust

Vedenina L.G. (2000) The theory of intercultural communication and the meaning of the word. Foreign languages at school. 5, 72-76.

Tsvetkova S.E. (2010) Formation of intercultural communicative competence among students of economic specialties: monograph. S.E. Tsvetkova. 